\title{
Dichotomous roles of co-stimulatory molecules in diabetes mellitus
}

\author{
Ji-Xin Zhong ${ }^{1}$, Jie Chen ${ }^{2,3}$, Xiaoquan Rao² and Lihua Duan ${ }^{4}$ \\ ${ }^{1}$ Department of Endocrinology, Central Hospital of Wuhan, Wuhan, Hubei, China 430061 \\ ${ }^{2}$ Cardiovascular Research Institute, School of Medicine, Case Western Reserve University, Cleveland, Ohio, USA 44106 \\ ${ }^{3}$ Basic Medical Department of Medical College, Xiamen University, Xiamen, China 361102 \\ ${ }^{4}$ Department of Rheumatology and Clinical Immunology, The First Affiliated Hospital of Xiamen University, Xiamen, Fujian, \\ China 361003
}

Correspondence to: Lihua Duan, email: Ih-duan@163.com

Keywords: co-stimulatory molecule; diabetes mellitus; dendritic cells; macrophage; CD28

Received: June 10, $2017 \quad$ Accepted: November 15, $2017 \quad$ Published: December 07, 2017

Copyright: Zhong et al. This is an open-access article distributed under the terms of the Creative Commons Attribution License 3.0 (CC BY 3.0), which permits unrestricted use, distribution, and reproduction in any medium, provided the original author and source are credited.

\section{ABSTRACT}

Numerous studies have established the importance of immune dysfunction in the development of diabetes mellitus, including typ1 and typ 2 diabetes, and it is worth noting that $T$ cell activation acts a key role in the pathogenesis of loss of $\beta$ cell mass, adipose inflammation and insulin resistance. Regarding as an important checkpoint in the process of $\mathrm{T}$ cell activation, co-stimulatory molecules interaction between antigen present cells and $T$ cells have been identified the critical role in the development of diabetes mellitus. Thus, blockage of co-stimulatory dyads interaction between antigen present cells and $\mathrm{T}$ cells was supposed to a potential of therapeutic strategies. However, studies also showed that inhibition or deletion of some costimulatory molecules do not always reduce the development of diabetes, and even exacerbate the disease activity. Here, in this context, we highlight the dichotomous role of co-stimulatory molecules interaction in the pathogenesis of diabetes.

\section{INTRODUCTION}

Diabetes mellitus is characterized by chronic hyperglycemia, which is resulted from the loss of $\beta$ cell mass or loss of insulin sensitivity [1-3]. Long-term improper control of blood glucose homeostasis predisposes patients to the development of diverse complications such as diabetic retinopathy [4], nephropathy [5], neuropathy [6], foot ulcers [7], and cardiovascular diseases [8]. Now it is well-accepted that abnormal immune response including both innate and adaptive immunity plays a critical role in the development of $\beta$ cell destruction and insulin resistance, although the underlying mechanisms remains elusive [9-11]. The co-stimulatory molecules are important regulators of immune activation via providing second signal for $\mathrm{T}$ cells activation [12]. Therefore, most studies have shown that interaction of co-stimulatory molecules exhibits a pathogenic role in autoimmune diseases [13-15]. Remarkably, B7/CD28 interaction is the vitally important second signal [16-18]. However, increasing evidence has suggested that some co- stimulatory signaling pathways may have a protective role in diabetes pathogenesis. Here, we review dichotomous role of these co-stimulatory molecules serve complicated roles in diabetes mellitus, especial B7/CD28.

Co-stimulatory molecules and diabetes

When the body encounters foreign antigens or endogenous danger signals, immune response usually initiates. The innate immune cells, especially the professional antigen present cells (APCs), play a crucial role in uptaking and processing pathogenic substance present the antigen to T cells through MHC molecules $[12,18]$, which results in cellular and humoral immunity. In addition to presenting antigens to T cells, APCs also express co-stimulatory molecules which are regulated by the exogenous pathogens or endogenous alarmins [such as high mobility group protein 1 (HMGB1), heat shock protein 70 (HSP70) as well as interleukin-33 (IL-33)], providing the second signal for $T$ cell activation [19]. The second signal is initiated by the interaction between co- 
stimulatory molecules expressed on the APCs and their corresponding ligands on the surface of T and B cells [20]. Like the neural synapse, the co-stimulatory dyads form an immunological synapse which is very important for the $\mathrm{T}$ or B cells activation [21]. In the absence of the second signal, the interaction of antigen-MHC complex with TCR or BCR, also known as the first signal, is insufficient to activate the $T$ cells or $B$ cells, leading to $T$ cell and $B$ cell anergy or apoptosis [20]. A number of co-stimulatory molecules have been identified, among which CD28/B7, CD40L/CD40, PD-1/PD-L1 and ICOS/ICOSL are the best-characterized co-stimulatory dyads involved in the immune synapse and immune cells activation.

Type 1 diabetes mellitus (T1DM) is the consequence of the autoimmune mediating pancreatic insulin-producing $\beta$ cells damage and loss [3]. Inflammatory autoreactive $\mathrm{T}$ cells, escaping from central and peripheral tolerance recognize pancreatic islet antigens, can be activated in the pancreatic lymph nodes. Activated T cells then migrate to local pancreatic islet and induce an inflammatory microenvironment, recruiting macrophage and neutrophil infiltration and leading to pancreas islet damage and injury [22]. Of note, obesity-associated inflammation is widely believed to play a key pathogenic role in the development of obesity-induced insulin resistance and type 2 diabetes mellitus (T2DM). Innate immune activation typified by infiltrating macrophages is deemed to represent important mediators of obesity-related complications [11, 23, 24]. Keeping with previous reports, our recent work also demonstrated that a critical role acted by adipose macrophages in $\mathrm{T}$ cells immune responses during this process [25].

The co-stimulatory molecules mediating the interaction between T cells and APCs have been linked to the development of abnormal immune response [20]. Therefore, inhibition of co-stimulatory molecules interaction has been suggested to modulate $\mathrm{T}$ cell activation. Lots of studies have indicated a protective role of co-stimulatory inhibition in the development of many disease, such as experimental allergic encephalomyelitis (EAE) [26-29], allograft transplantation [30-32], arthritis $[33,34]$, and hypertension $[35,36]$. Furthermore, the abnormal immune response induced by co-stimulatory molecules also result in $\beta$ cell loss and insulin resistance in T1DM and T2DM [9, 22, 37]. Thus, dampening inflammation induced by autoimmune response become a potential therapeutic method in diabetes. However, increasing evidences suggest a protective role by some co-stimulatory molecules dyads in diabetes pathogenesis. Below we review the complicated roles of co-stimulatory molecules dyads in the development of diabetes.

\section{Role of $\mathrm{B} 7 / \mathrm{CD} 28$ in diabetes}

Two signals are required for full activation of naive CD4+ T lymphocytes as described [20]. T cell will be anergy or undergo apoptosis in the absence of second signal [38]. Therefore, co-stimulation inhibition shows a great therapeutic potential in immune-mediated diseases. B7 molecules, including B7-1 (CD80) and B7-2 (CD86), are the best-characterized co-stimulatory molecules and mainly expressed on APCs such as dendritic cells (DCs), B cells, and macrophages [17]. Nevertheless, Study have shown that B7-2 might be more important in the initiation of immune responses, as its expression is rapidly upregulated when APCs encounter endogenous damage alarmin or foreign bodies, yet B7-1 is up-regulated in the later phase during the immune response [39, 40]. Through binding its specific receptor CD28, B7 activates protein kinase $\mathrm{C} \theta(\mathrm{PKC} \theta)$ and RAS guanyl nucleotidereleasing protein (RASGRP) [41, 42], which promotes $\mathrm{T}$ cell activation, proliferation, and anti-apoptosis. Of note, the co-inhibitory receptor CTLA-4 also shares the ligands (B7-1 and B7-2) with CD28 [40]. Generally, CTLA4 is highly expressed in activated T cells, which is the self-control for preventing excessive immune response by binding to B7-1 or B7-2 [29, 43]. This co-inhibitory receptor CTLA-4 attracts increasing intention, because of its potential in immune regulation and higher binding affinity compared with CD28. CTLA-4 Ig has been used in the treatment of autoimmune disease [29, 33] and transplant rejection $[44,45]$. Overall, the opposing roles of CD28 and CTLA4 are considered a prototypical immune checkpoint for the immune response through competing pro- and anti-inflammatory effects.

Interestingly, studies have demonstrated that basal B7-1 and B7-2 expression is also necessary to prevent autoimmunity by sustaining regulatory $\mathrm{T}$ (Treg) cell populations [46-49]. In our previous investigation, we also elucidated a homeostatic role of B7-mediated costimulation in diet-induced obesity using CD80/CD86 double knockout (B7 KO) mice and investigated the relevance of this process in humans with obesity and IR [50]. Our results suggested an essential role for B7 in maintaining Tregs and adipose homeostasis and may have important implications in immunotherapies targeting costimulation in type 2 diabetes.

As is well-known, interaction between B7 and CD28 promotes inflammation, while there is difference between the function of B7-1 and B7-2. In the development of type 1 diabetes in the NOD mouse, a distinct regulation of B7-1 and B7-2 were observed. At the onset of insulitis, mice treated with CTLA4 Ig or a blocking B7-2 antibody did not develop diabetes. However, there is no significant effect when CTLA4 Ig or a blocking B7-2 antibody administered late. Consistently, a delayed development of diabetes was seen in B7-2 knockout NOD mice, where islet-reactive CD4 $\mathrm{T}$ cells were defective. In contrast to the effect of B7-2 inhibition, B7-1 neutralization or gene deficiency causes exacerbation of disease, the lack of B7-1 significantly accelerated the development of disease accompanied by enhanced expansion, survival, 
and effector function of islet specific $\mathrm{T}$ cells in periphery $[51,52]$. Furthermore, B7-1 deficiency mice showed a significant reduction in immunosuppressive Tregs cells [52]. These results suggest that B7 may play complicated role in the development of autoimmunity. Likely, in our previous study, expression of B7-1 and B7-2 was negatively correlated with the degree of IR and adipose tissue macrophage infiltration in both humans and mice. Furthermore, instead of promoting inflammation, ablation of CD80/CD86 by double gene knockout defects Tregs development and proliferation in mice, and exhibits enhanced adipose macrophage inflammation and IR under high-fat diet feed. Conversely, adoptive transfer of Tregs reversed IR and adipose inflammation in B7 KO mice [50]. Taken together, above studies of B7/CD28 co-stimulatory molecules show a complicated role in development of immune-mediated disease, including diabetes.

\section{Beneficial roles of $\mathrm{B} 7 / \mathrm{CD} 28$ in diabetes}

Although B7/CD28 co-stimulation participates in the induction and progression of autoimmune diseases, it has also been demonstrated that B7/CD28 co-stimulatory molecules interaction is substantial for Tregs development and proliferation. To examine the role of B7/CD28 in the development of EAE, CTLA-4 Ig was administrated to the mice. Unexpectedly, B7 blockade with CTL1-4 Ig exacerbated disease signs and exhibited more severe CNS inflammation and demyelination, which was associated with the increased inflammatory cytokines IL-17 and IFN- $\gamma$ [29]. Similarly, in our previous study, CD80/CD86 was found to be essential for Tregs development and proliferation in obese mice and human, instead of promoting inflammation [50]. Furthermore, a subpopulation of CD4+ T subsets, characterized by low CD28 expression, is resistant to apoptotic signals and lives longer in vivo $[53,54]$. The CD4 + CD28- T cells shows an atherogenic and plaque-destabilizing property [55-59]. It is well known that the diabetes patients are at high risks of atherosclerosis. Therefore, these $\mathrm{T}$ cell subpopulations were investigated in diabetes patients. When compared with non-diabetic individuals, T2DM patients with proliferative diabetic retinopathy showed a higher percentage of CD4 + CD28- population [60]. A study showed that CD4 + CD28- T cells potentially drive the severity of the disease through producing IL17, and IL-17 expression of CD4 + CD28- T cells was regulated by $\mathrm{NKG} 2 \mathrm{D}$. In addition, when compared to non-diabetic individuals, CD4 + CD28- NKG2D + T cells subpopulation is increased in T2DM patients [61]. Shi B et. al showed that advanced glycation end products (AGEs) effectively enhanced these subset $\mathrm{T}$ cells proliferation in patients with T2DM, and the higher level of CD4 + CD28- $T$ cells is closely associated with the status of macrovascular atherosclerosis in patients with T2DM
[62]. Similarly, by means of ultrasound image to analyze the atherosclerotic plaque in the common carotid artery (CCA), CD4 + CD28- lymphocytes reveals a positive correlation with the number of atherosclerotic plaques within the CCA. In a clinical follow-up observation, CD4 + CD28- T cells are correlated with the occurrence of a first cardiovascular event and with a worse outcome after an ACS in DM patients [63]. These data revealed that the expression of CD28 molecules on CD4 + cell is vital for immune homeostasis in T2DM.

Furthermore, lack of B7/CD28 interaction also results in a limited numbers of regulatory $T$ cells and aggressive disease progression in the T1DM NOD mice [64]. Treg cells were markedly decrease in the B7-1/ B7-2-deficient and CD28-deficient NOD mice [49]. Additionally, the percentage of CD4 + CD28 + T cells and IL-2 production were also decreased along with aging, which resulted in impired Tregs function in NOD mice [65]. Recently, multipotent stem cells received huge attention in the treatment of many diseases due to its immunoregulatory and tissue repair functions [66-70]. In a clinical trial, the $\mathrm{C}$-peptide levels, median glycated hemoglobin A1C (HbA1C) values, and the median daily dose of insulin were markedly improved in T1DM patients treated with cord blood-derived multipotent stem cells. Study also showed that the improvement was associated with increased expression of CD28, ICOS and the number of Tregs [71]. This study sustains the concept that CD28 plays an immunoregulatory function. Keeping with above reports, B7-1 gene knockout NOD mice showed a diminished amount and expansion in Tregs, accompanied by increased survival and amplification of auto reactive $\mathrm{T}$ cells [52]. Bour-Jordan $\mathrm{H}$ et.al further demonstrated that B7-1 overexpression on B cells completely protected NOD mice from developing diabetes [72]. These studies suggest a protective role of $\mathrm{B} 7 / \mathrm{CD} 28$ in the development of diabetes.

\section{The pro-inflammation of $\mathrm{B} 7 / \mathrm{CD} 28$ in diabetes}

As is well-known, the interaction between B7 and CD28 is critical for the second signal of $\mathrm{T}$ cell activation and promotes inflammation [18]. In a case report, the patient with T2DM showed a dramatic improvement in insulin resistance when blockage CD28 activity by CTLA4-Ig infusion [73]. Furthermore, high glucose conditions promoted podocytes to express B7-1 both in vitro and in vivo. Treatment with CTLA4-Ig inhibited the apoptosis of podocytes, leading to an improvement of urinary albumin excretion and kidney pathology in these animals. Besides, the B7-1 expression is also up-regulated in podocytes from kidney biopsy specimens of T2DM patients [74]. Moreover, the expression of B7-2 has also been shown to increase in gestational diabetes mellitus (GDM) patients [75, 76]. Although not statistically significant (probably due to the small sample size), 
Schliefsteiner et al. reported that there was an increase of B7-2 in parallel with proinflammatory cytokines IL-1 $\beta$ and IL-6 in patients with GDM [76]. The expression of CD28, the binding partner of B7, was also increased in the peripheral T cells from patients with GDM [77].

A single-nucleotide polymorphisms (SNPs) analysis demonstrated that CD28 might contribute to the risk of T1DM [78]. In addition, a recent study showed that mice deficient for CTLA-4 or treated with anti-CTLA-4 antibody exhibited spontaneous follicular T cells ( $\mathrm{Tfh}$ ) differentiation by enhancing the strength of CD28 ligation with B7-1 and B7-2 [79]. IL-21, a critical cytokine in autoimmunity, can promote autoimmune response through up-regulating B7-2 on B cells [80]. These studies showed a great potential of B7/CD28 in the treatment of autoimmune diseases. Indeed, a marked reduction of spontaneously activated CD4 T cells and islet-specific CD4 T cell expansion and enhanced CD4 $\mathrm{T}$ cell death were observed in B7-2 knockout NOD mice. Interestingly, a significant reduction of Treg was not seen in the peripheral compartments of B7-2 KO mice [81]. Contrary to the inflammatory characteristic of CD4 + CD28- subset T cell, a CD8 + subpopulation with lower expression of CD28 exhibits an anti-inflammatory function [82]. In the peripheral blood mononuclear cells from juveniles with T1DM, CD8 + CD28- T cell subset was significantly reduced and correlated with disease duration. Moreover, CD8 + CD28- subpopulation was also significantly lowered in multiple sclerosis patients as well [83]. In the absence of Tec family kinase ITK, a CD28 downstream signaling molecule, there was a profound diminishment of islet-infiltrating inflammatory cells in mice with T1DM [84].

Taken together, B7/CD28 co-stimulation has divergent effects on the pathogenesis of diabetes mellitus in the different context of disease, which leads to a great barrier for the therapeutic method in diabetes. While not only complicated role of B7/CD28 dyad, many other costimulatory molecule dyads also exhibit a dichotomous role in the pathogenesis of diabetes. Below, we discuss some other co-stimulatory molecules that play an essential role in diabetes development.

\section{Complicated role of other co-stimulatory molecules in diabetes}

\section{ICOS}

Inducible co-stimulator (ICOS), a member of the CD28 family, is expressed after $\mathrm{T}$ cell activation [85]. The deletion of ICOS in T cells results in a decreased production of the Th1 cytokine IFN- $\gamma$ without affecting the numbers of regulatory $\mathrm{T}$ cells. ICOS plays a considerable role in the induction of the autoimmunemediated diabetes [86]. However, there was also a study reporting that the absence of ICOS exacerbates the disease activity in experimental models of diabetes by ablating
Treg function [87]. This difference might be caused by the different function of ICOS on different cells, which leads to discrepant outcome.

\section{B7-H4}

A member of the B7 family, is expressed on the cell membrane of APCs and up-regulated when they activated by exogenous and endogenous stimulator [88, 89]. However, its specific receptors remain unknown. Previous study showed that B7-H4 deficiency increased the incidence and severity of EAE and collagen-induced arthritis (CIA) [90-92]. Furthermore, B7-H4 inhibits islet allograft rejection and decreases lymphocyte proliferation [93]. Recent studies also indicate a suppressive function of B7-H4 in the development of diabetogenic autoimmunity. An increased level of soluble B7-H4 (sVTCN1) was detected in T1DM patients, which is correlated with the aggressive pace of disease. The sVTCN1 lost its immunosuppressive function on inhibiting diabetogenic $\mathrm{T}$ cells. Therefore, inhibiting the cleavage of membrane B7-H4 may serve as a potential therapeutic strategy [94, 95]. Independent of inhibiting the recruitment of activated CD4 + and CD8 + T cells to islets, B7-H4 Ig treatment significantly postponed the disease onset and reduced incidence of diabetes in NOD mice due to a transient increase of Treg cells population [96]. Furthermore, $\beta$ cell-specific B7-H4 overexpression protected against allograft rejection [97]. Unexpectedly, endogenous B7H4 showed a defect in inhibitory costimulation, but augments the activation of diabetogenic T cell during T1D development [95]. Further study should be carried out to address the exact role of B7-H4 in the immune modulation during the development of diabetes.

\section{CD40/CD40L}

The costimulatory molecule CD40 and its ligand CD40L (CD154) are expressed by T cells, B cells, APCs, pancreatic islet $\beta$ cells, and pancreatic ductal cells [12, 98]. In T1DM animal model NOD mice, blockage of CD40L during early diabetes ameliorates spontaneous disease onset, resulting from the decreased number of auto-reactive T cells [99-101]. In parallel with T1DM, CD40-CD40L interactions showed a pro-inflammatory role of in adipose tissue inflammation. Deletion of CD40L protected against weight gain, adipose tissue inflammation, hepatosteatosis, and insulin resistance after high-fat diet feeding [102-105]. However, it has been demonstrated that CD40-/- mice on high-fat diet displayed increased weight gain, impaired insulin secretion, and upregulated pro-inflammatory cytokines compared to the wild type mice. Further data revealed that the expression of pro-inflammatory cytokines inhibited by CD40 activation only found in T cells, but not in B cells or macrophages. This study provided the evidence 
that protective effect of CD40 was closely associated with CD40 signaling on T cells, which improved adipose tissue inflammation and metabolic complications [106]. These data suggest CD40L/CD40 also plays a complicated role in the development of obesity.

\section{4-1BB/4-1BBL}

As a member of the TNF receptor superfamily, 4-1BB provides a co-stimulatory signal through binding to its ligand 4-1BBL $[12,107]$. 4-1BB is expressed on adipocytes and macrophages, and is upregulated by obesity-related factors [108]. 4-1BB and/or 4-1BBL agonists activate inflammatory signaling molecules in adipocytes and macrophages [109]. In consistency, 4-1BB deficiency protects against HFD-induced obesity, glucose intolerance, and fatty liver disease though decrease adipose infiltration of macrophages/T cells, and tissue levels of inflammatory cytokines [110]. Unexpectedly, anti-4-1BB scFv transgenic NOD mice developed more severe diabetes than their non-transgenic littermates, as evidenced by earlier onset, faster diabetic process, and higher mortality rate [111].

\section{CONCLUSIONS}

Heretofore, although lots of basic and clinical studies of co-stimulatory molecules have been investigated in the pathogenesis of diabetes, the roles and mechanisms remains ill defined. Due to the complicated and dedicated micro-environment of disease, contradictory role of co-stimulatory dyads is often observed in the development of diabetes. The possible reasons for the contradictory roles of co-stimulatory dyads in diabetes mellitus might be as follow: 1) The basal expression of co-stimulatory molecules such as B7-1 and B7-2 is required to prevent heightened inflammatory response by sustaining Treg populations; 2) The expression of different co-stimulatory molecules may be regulated differentially by a variety of inflammatory cytokines during the process of diabetes; 3 ) Different co-stimulatory molecules have distinct effects on different cell populations, which leads to discrepant outcomes; 4) The source (exogenous versus endogenous) of co-stimulatory molecules such as B7-H4 might affect their functions on immune activation; 5) In addition, the intervention methods to block co-stimulatory molecules (eg. Antibody-mediated neutralization and administration of recombinant fusion proteins) might affect the function of other co-stimulatory molecules. For example, CTLA4 depletion also promotes the ligation between $\mathrm{B} 7$ and CD28. Therefore, further studies are required to fully understand the pathophysiological roles of co-stimulation in diabetes and develop immunomodulatory therapeutics against the inflammatory process in metabolic disease.

\section{Author contributions}

L.H.D., J.C. and J.X.Z designed, prepared and revised the manuscript. X.Q.R. and J.X.Z. were involved in the preparation and critical intellectual revision of the paper.

\section{CONFLICTS OF INTEREST}

The authors declare no conflicts of interest within this manuscript.

\section{FUNDING}

This work was supported by grants from NIH (K01 DK105108), American Heart Association (17GRNT33670485), American Association of Immunologists (CIIF-8745), the National Natural Science Foundation of China (81670431, 81671544, 81302564), Fujian Province health planning of young outstanding talents training project (no.2016-ZQN-82), and Natural Science Foundation of Fujian Provincial Department of Science and Technology (2017J01356).

\section{REFERENCES}

1. Reaven GM. Banting lecture 1988. Role of insulin resistance in human disease. Diabetes. 1988; 37: 1595-607.

2. Weyer C, Bogardus C, Mott DM, Pratley RE. The natural history of insulin secretory dysfunction and insulin resistance in the pathogenesis of type 2 diabetes mellitus. J Clin Invest. 1999; 104:787-94. https://doi.org/10.1172/ JCI7231.

3. Daneman D. Type 1 diabetes. Lancet. 2006; 367:847-58. https://doi.org/10.1016/S0140-6736(06)68341-4.

4. Roy S, Kern TS, Song B, Stuebe C. Mechanistic Insights into Pathological Changes in the Diabetic Retina: Implications for Targeting Diabetic Retinopathy. Am J Pathol. 2017; 187:9-19. https://doi.org/10.1016/j. ajpath.2016.08.022.

5. Artunc F, Schleicher E, Weigert C, Fritsche A, Stefan N, Haring HU. The impact of insulin resistance on the kidney and vasculature. Nat Rev Nephrol. 2016; 12:721-37. https:// doi.org/10.1038/nrneph.2016.145.

6. Johnston SS, Udall M, Alvir J, McMorrow D, Fowler R, Mullins D. Characteristics, treatment, and health care expenditures of Medicare supplemental-insured patients with painful diabetic peripheral neuropathy, post-herpetic neuralgia, or fibromyalgia. Pain Med. 2014; 15:562-76. https://doi.org/10.1111/pme.12328.

7. Cychosz CC, Phisitkul P, Belatti DA, Wukich DK. Preventive and Therapeutic Strategies for Diabetic Foot Ulcers. Foot Ankle Int. 2016; 37:334-43. https://doi. org/10.1177/1071100715611951. 
8. Rouyard T, Kent S, Baskerville R, Leal J, Gray A. Perceptions of risks for diabetes-related complications in Type 2 diabetes populations: a systematic review. Diabet Med. 2016. https://doi.org/10.1111/dme.13285.

9. Sell H, Habich C, Eckel J. Adaptive immunity in obesity and insulin resistance. Nat Rev Endocrinol. 2012; 8:709-16. https://doi.org/10.1038/nrendo.2012.114.

10. Pedicino D, Liuzzo G, Trotta F, Giglio AF, Giubilato S, Martini F, Zaccardi F, Scavone G, Previtero M, Massaro G, Cialdella P, Cardillo MT, Pitocco D, et al. Adaptive immunity, inflammation, and cardiovascular complications in type 1 and type 2 diabetes mellitus. J Diabetes Res. 2013; 2013:184258. https://doi.org/10.1155/2013/184258.

11. Fernandez-Real JM, Pickup JC. Innate immunity, insulin resistance and type 2 diabetes. Diabetologia. 2012; 55:2738. https://doi.org/10.1007/s00125-011-2387-y.

12. Chen L, Flies DB. Molecular mechanisms of T cell costimulation and co-inhibition. Nat Rev Immunol. 2013; 13:227-42. https://doi.org/10.1038/nri3405.

13. Girvin AM, Dal Canto MC, Rhee L, Salomon B, Sharpe A, Bluestone JA, Miller SD. A critical role for B7/ CD28 costimulation in experimental autoimmune encephalomyelitis: a comparative study using costimulatory molecule-deficient mice and monoclonal antibody blockade. J Immunol. 2000; 164:136-43.

14. O’Neill SK, Cao Y, Hamel KM, Doodes PD, Hutas G, Finnegan A. Expression of CD80/86 on B cells is essential for autoreactive $\mathrm{T}$ cell activation and the development of arthritis. J Immunol. 2007; 179:5109-16.

15. Racke MK, Scott DE, Quigley L, Gray GS, Abe R, June $\mathrm{CH}$, Perrin PJ. Distinct roles for B7-1 (CD-80) and B7-2 (CD-86) in the initiation of experimental allergic encephalomyelitis. J Clin Invest. 1995; 96:2195-203. https://doi.org/ 10.1172/JCI118274.

16. McAdam AJ, Schweitzer AN, Sharpe AH. The role of B7 co-stimulation in activation and differentiation of CD4+ and CD8+ T cells. Immunol Rev. 1998; 165:231-47.

17. Harris NL, Ronchese F. The role of B7 costimulation in T-cell immunity. Immunol Cell Biol. 1999; 77:304-11. https://doi.org/10.1046/j.1440-1711.1999.00835.x.

18. Lenschow DJ, Walunas TL, Bluestone JA. CD28/B7 system of T cell costimulation. Annu Rev Immunol. 1996; 14:23358. https://doi.org/10.1146/annurev.immunol.14.1.233.

19. Bertheloot D, Latz E. HMGB1, IL-1alpha, IL-33 and S100 proteins: dual-function alarmins. Cell Mol Immunol. 2016. https://doi.org/10.1038/cmi.2016.34.

20. Zhu Y, Yao S, Chen L. Cell surface signaling molecules in the control of immune responses: a tide model. Immunity. 2011; 34:466-78. https://doi.org/10.1016/j. immuni.2011.04.008.

21. Gonzalez PA, Carreno LJ, Figueroa CA, Kalergis AM. Modulation of immunological synapse by membrane-bound and soluble ligands. Cytokine Growth Factor Rev. 2007; 18:19-31. https://doi.org/10.1016/j.cytogfr.2007.01.003.
22. Peakman M. Immunological pathways to beta-cell damage in Type 1 diabetes. Diabet Med. 2013; 30:147-54. https:// doi.org/10.1111/dme.12085.

23. Lumeng CN, Bodzin JL, Saltiel AR. Obesity induces a phenotypic switch in adipose tissue macrophage polarization. J Clin Invest. 2007; 117:175-84. https://doi. org/10.1172/JCI29881.

24. Bouloumie A, Curat CA, Sengenes C, Lolmede K, Miranville A, Busse R. Role of macrophage tissue infiltration in metabolic diseases. Curr Opin Clin Nutr Metab Care. 2005; 8:347-54.

25. Zhong J, Rao X, Deiuliis J, Braunstein Z, Narula V, Hazey J, Mikami D, Needleman B, Satoskar AR, Rajagopalan S. A potential role for dendritic cell/macrophage-expressing DPP4 in obesity-induced visceral inflammation. Diabetes. 2013; 62:149-57. https://doi.org/10.2337/db12-0230.

26. Du C, Bright JJ, Sriram S. Inhibition of CD40 signaling pathway by tyrphostin A1 reduces secretion of IL-12 in macrophage, Th1 cell development and experimental allergic encephalomyelitis in SJL/J mice. J Neuroimmunol. 2001; 114:69-79.

27. McArdel SL, Brown DR, Sobel RA, Sharpe AH. AntiCD48 Monoclonal Antibody Attenuates Experimental Autoimmune Encephalomyelitis by Limiting the Number of Pathogenic CD4+ T Cells. J Immunol. 2016; 197:3038-48. https://doi.org/10.4049/jimmunol.1600706.

28. Xiao X, Shi X, Fan Y, Wu C, Zhang X, Minze L, Liu W, Ghobrial RM, Lan P, Li XC. The Costimulatory Receptor OX40 Inhibits Interleukin-17 Expression through Activation of Repressive Chromatin Remodeling Pathways. Immunity. 2016; 44:1271-83. https://doi.org/10.1016/j. immuni.2016.05.013.

29. Vogel I, Kasran A, Cremer J, Kim YJ, Boon L, Van Gool SW, Ceuppens JL. CD28/CTLA-4/B7 costimulatory pathway blockade affects regulatory T-cell function in autoimmunity. Eur J Immunol. 2015; 45:1832-41. https:// doi.org/10.1002/eji.201445190.

30. Xu J, Huang B, Xiong P, Feng W, Xu Y, Fang M, Zheng F, Gong F. Soluble mouse B7-H3 down-regulates dendritic cell stimulatory capacity to allogenic $\mathrm{T}$ cell proliferation and production of IL-2 and IFN-gamma. Cell Mol Immunol. 2006; 3:235-40.

31. Dai H, Zhu H, Lei P, Yagita H, Liu J, Wen X, Zhou W, Gong F, Shen G, Fang M. Programmed death-1 signaling is essential for the skin allograft protection by alternatively activated dendritic cell infusion in mice. Transplantation. 2009; 88:864-73. https://doi.org/10.1097/ TP.0b013e3181b6ea74.

32. Ford ML. T Cell Cosignaling Molecules in Transplantation. Immunity. 2016; 44:1020-33. https://doi.org/10.1016/j. immuni.2016.04.012.

33. Cutolo M, Sulli A, Paolino S, Pizzorni C. CTLA-4 blockade in the treatment of rheumatoid arthritis: an update. Expert Rev Clin Immunol. 2016; 12:417-25. https://doi.org/10.15 86/1744666X.2016.1133295. 
34. Ceeraz S, Nowak EC, Burns CM, Noelle RJ. Immune checkpoint receptors in regulating immune reactivity in rheumatic disease. Arthritis Res Ther. 2014; 16:469.

35. Lichtman AH. T cell costimulatory and coinhibitory pathways in vascular inflammatory diseases. Front Physiol. 2012; 3:18. https://doi.org/10.3389/fphys.2012.00018.

36. Kirabo A, Fontana V, de Faria AP, Loperena R, Galindo CL, Wu J, Bikineyeva AT, Dikalov S, Xiao L, Chen W, Saleh MA, Trott DW, Itani HA, et al. DC isoketal-modified proteins activate $\mathrm{T}$ cells and promote hypertension. J Clin Invest. 2014; 124:4642-56. https://doi.org/10.1172/ JCI74084.

37. Seijkens T, Kusters P, Chatzigeorgiou A, Chavakis T, Lutgens E. Immune cell crosstalk in obesity: a key role for costimulation? Diabetes. 2014; 63:3982-91. https://doi. org/10.2337/db14-0272.

38. Choi S, Schwartz RH. Molecular mechanisms for adaptive tolerance and other T cell anergy models. Semin Immunol. 2007; 19:140-52. https://doi.org/10.1016/j. smim.2007.02.005.

39. Lenschow DJ, Sperling AI, Cooke MP, Freeman G, Rhee L, Decker DC, Gray G, Nadler LM, Goodnow CC, Bluestone JA. Differential up-regulation of the B7-1 and B7-2 costimulatory molecules after Ig receptor engagement by antigen. J Immunol. 1994; 153:1990-7.

40. Sharpe AH, Freeman GJ. The B7-CD28 superfamily. Nat Rev Immunol. 2002; 2:116-26. https://doi.org/10.1038/nri727.

41. Isakov $\mathrm{N}$, Altman A. PKC-theta-mediated signal delivery from the TCR/CD28 surface receptors. Front Immunol. 2012; 3:273. https://doi.org/10.3389/fimmu.2012.00273.

42. Sedwick CE, Altman A. Perspectives on PKCtheta in T cell activation. Mol Immunol. 2004; 41:675-86. https://doi. org/10.1016/j.molimm.2004.01.007.

43. Stumpf M, Zhou X, Bluestone JA. The B7-independent isoform of CTLA-4 functions to regulate autoimmune diabetes. J Immunol. 2013; 190:961-9. https://doi. org/10.4049/jimmunol.1201362.

44. Kim I, Wu G, Chai NN, Klein AS, Jordan SC. Immunological characterization of de novo and recall alloantibody suppression by CTLA4Ig in a mouse model of allosensitization. Transpl Immunol. 2016; 38:84-92. https:// doi.org/10.1016/j.trim.2016.08.001.

45. Vincenti F, Rostaing L, Grinyo J, Rice K, Steinberg S, Gaite L, Moal MC, Mondragon-Ramirez GA, Kothari J, Polinsky MS, Meier-Kriesche HU, Munier S, Larsen CP. Belatacept and Long-Term Outcomes in Kidney Transplantation. N Engl J Med. 2016; 374:333-43. https://doi.org/10.1056/ NEJMoa1506027.

46. Lohr J, Knoechel B, Jiang S, Sharpe AH, Abbas AK. The inhibitory function of B7 costimulators in $\mathrm{T}$ cell responses to foreign and self-antigens. Nat Immunol. 2003; 4:664-9. https://doi.org/10.1038/ni939.

47. Moser EK, Hufford MM, Braciale TJ. Late engagement of CD86 after influenza virus clearance promotes recovery in a FoxP3+ regulatory $\mathrm{T}$ cell dependent manner. PLoS Pathog. 2014; 10:e1004315. https://doi.org/10.1371/journal. ppat.1004315.

48. Ertelt JM, Buyukbasaran EZ, Jiang TT, Rowe JH, Xin L, Way SS. B7-1/B7-2 blockade overrides the activation of protective CD8 T cells stimulated in the absence of Foxp3+ regulatory T cells. J Leukoc Biol. 2013; 94:367-76. https:// doi.org/10.1189/jlb.0313118.

49. Salomon B, Lenschow DJ, Rhee L, Ashourian N, Singh B, Sharpe A, Bluestone JA. B7/CD28 costimulation is essential for the homeostasis of the CD4+CD25+ immunoregulatory $\mathrm{T}$ cells that control autoimmune diabetes. Immunity. 2000; 12:431-40.

50. Zhong J, Rao X, Braunstein Z, Taylor A, Narula V, Hazey J, Mikami D, Needleman B, Rutsky J, Sun Q, Deiuliis JA, Satoskar AR, Rajagopalan S. T-cell costimulation protects obesity-induced adipose inflammation and insulin resistance. Diabetes. 2014; 63:1289-302. https://doi. org/10.2337/db13-1094.

51. Lenschow DJ, Ho SC, Sattar H, Rhee L, Gray G, Nabavi N, Herold KC, Bluestone JA. Differential effects of anti-B7-1 and anti-B7-2 monoclonal antibody treatment on the development of diabetes in the nonobese diabetic mouse. J Exp Med. 1995; 181:1145-55.

52. Yadav D, Fine C, Azuma M, Sarvetnick N. B7-1 mediated costimulation regulates pancreatic autoimmunity. Mol Immunol. 2007; 44:2616-24. https://doi.org/10.1016/j. molimm.2006.12.008.

53. Martens PB, Goronzy JJ, Schaid D, Weyand CM. Expansion of unusual CD4+ T cells in severe rheumatoid arthritis. Arthritis Rheum. 1997; 40:1106-14. https://doi. org/10.1002/1529-0131(199706)40:6\&1t;1106::AIDART14\&gt;3.0.CO;2-\#.

54. Vallejo AN, Weyand CM, Goronzy JJ. T-cell senescence: a culprit of immune abnormalities in chronic inflammation and persistent infection. Trends Mol Med. 2004; 10:119-24. https://doi.org/10.1016/j.molmed.2004.01.002.

55. Liuzzo G, Kopecky SL, Frye RL, O’Fallon WM, Maseri A, Goronzy JJ, Weyand CM. Perturbation of the T-cell repertoire in patients with unstable angina. Circulation. 1999; 100:2135-9.

56. Liuzzo G, Goronzy JJ, Yang H, Kopecky SL, Holmes DR, Frye RL, Weyand CM. Monoclonal T-cell proliferation and plaque instability in acute coronary syndromes. Circulation. 2000; 101:2883-8.

57. Zal B, Kaski JC, Arno G, Akiyu JP, Xu Q, Cole D, Whelan M, Russell N, Madrigal JA, Dodi IA, Baboonian C. Heat-shock protein 60-reactive CD4+CD28null $\mathrm{T}$ cells in patients with acute coronary syndromes. Circulation. 2004; 109:1230-5. https://doi.org/10.1161/01. CIR.0000118476.29352.2A.

58. Zal B, Kaski JC, Akiyu JP, Cole D, Arno G, Poloniecki J, Madrigal A, Dodi A, Baboonian C. Differential pathways govern CD4+ CD28- T cell proinflammatory and effector 
responses in patients with coronary artery disease. J Immunol. 2008; 181:5233-41.

59. Liuzzo G, Biasucci LM, Trotta G, Brugaletta S, Pinnelli M, Digianuario G, Rizzello V, Rebuzzi AG, Rumi C, Maseri A, Crea F. Unusual CD4+CD28null T lymphocytes and recurrence of acute coronary events. J Am Coll Cardiol. 2007; 50:1450-8. https://doi.org/10.1016/j.jacc.2007.06.040.

60. Canton A, Martinez-Caceres EM, Hernandez C, Espejo C, Garcia-Arumi J, Simo R. CD4-CD8 and CD28 expression in $\mathrm{T}$ cells infiltrating the vitreous fluid in patients with proliferative diabetic retinopathy: a flow cytometric analysis. Arch Ophthalmol. 2004; 122:743-9. https://doi. org/10.1001/archopht.122.5.743.

61. Phoksawat W, Jumnainsong A, Leelayuwat N, Leelayuwat C. Aberrant NKG2D expression with IL-17 production of $\mathrm{CD} 4+\mathrm{T}$ subsets in patients with type 2 diabetes. Immunobiology. 2016. https://doi.org/10.1016/j. imbio.2016.05.001.

62. Shi B, Du X, Wang Q, Chen Y, Zhang X. Increased PD-1 on CD4(+)CD28(-) T cell and soluble PD-1 ligand-1 in patients with T2DM: association with atherosclerotic macrovascular diseases. Metabolism. 2013; 62:778-85. https://doi. org/10.1016/j.metabol.2012.12.005.

63. Giubilato S, Liuzzo G, Brugaletta S, Pitocco D, Graziani F, Smaldone C, Montone RA, Pazzano V, Pedicino D, Biasucci LM, Ghirlanda G, Crea F. Expansion of CD4+CD28null T-lymphocytes in diabetic patients: exploring new pathogenetic mechanisms of increased cardiovascular risk in diabetes mellitus. Eur Heart J. 2011; 32:1214-26. https:// doi.org/10.1093/eurheartj/ehq499.

64. Tada A, Shimada A, Yamada T, Oikawa Y, Yamada Y, Okubo Y, Irie J, Bluestone JA, Itoh H. A mimic of viral double-stranded RNA triggers fulminant type 1 diabeteslike syndrome in regulatory $\mathrm{T}$ cell-deficient autoimmune diabetic mouse. J Immunol. 2011; 187:4947-53. https://doi. org/10.4049/jimmunol.1000837.

65. Sheu TT, Chiang BL, Yen JH, Lin WC. Premature CD4+ $\mathrm{T}$ cell aging and its contribution to lymphopenia-induced proliferation of memory cells in autoimmune-prone nonobese diabetic mice. PLoS One. 2014; 9:e89379. https://doi. org/10.1371/journal.pone.0089379.

66. Zhang X, Huang F, Chen Y, Qian X, Zheng SG. Progress and prospect of mesenchymal stem cell-based therapy in atherosclerosis. Am J Transl Res. 2016; 8:4017-24.

67. Zhao Y, Mazzone T. Human cord blood stem cells and the journey to a cure for type 1 diabetes. Autoimmun Rev. 2010; 10:103-7. https://doi.org/10.1016/j.autrev.2010.08.011.

68. Abdi R, Fiorina P, Adra CN, Atkinson M, Sayegh MH. Immunomodulation by mesenchymal stem cells: a potential therapeutic strategy for type 1 diabetes. Diabetes. 2008; 57:1759-67. https://doi.org/10.2337/db08-0180.

69. Uccelli A, Moretta L, Pistoia V. Mesenchymal stem cells in health and disease. Nat Rev Immunol. 2008; 8:726-36. https://doi.org/10.1038/nri2395.
70. Zhao Y, Huang Z, Qi M, Lazzarini P, Mazzone T. Immune regulation of $\mathrm{T}$ lymphocyte by a newly characterized human umbilical cord blood stem cell. Immunol Lett. 2007; 108:78-87. https://doi.org/10.1016/j.imlet.2006.10.007.

71. Zhao Y, Jiang Z, Zhao T, Ye M, Hu C, Yin Z, Li H, Zhang Y, Diao Y, Li Y, Chen Y, Sun X, Fisk MB, et al. Reversal of type 1 diabetes via islet beta cell regeneration following immune modulation by cord blood-derived multipotent stem cells. BMC Med. 2012; 10:3. https://doi.org/10.1186/17417015-10-3.

72. Bour-Jordan H, Salomon BL, Thompson HL, Santos R, Abbas AK, Bluestone JA. Constitutive expression of B7-1 on B cells uncovers autoimmunity toward the B cell compartment in the nonobese diabetic mouse. J Immunol. 2007; 179:1004-12.

73. Ursini F, Mauro D, Naty S, Gagliardi D, Grembiale RD. Improvement in insulin resistance after short-term treatment with abatacept: case report and short review. Clin Rheumatol. 2012; 31:1401-2. https://doi.org/10.1007/ s10067-012-2034-0.

74. Fiorina P, Vergani A, Bassi R, Niewczas MA, Altintas MM, Pezzolesi MG, D'Addio F, Chin M, Tezza S, Ben Nasr M, Mattinzoli D, Ikehata M, Corradi D, et al. Role of podocyte B7-1 in diabetic nephropathy. J Am Soc Nephrol. 2014; 25:1415-29. https://doi.org/10.1681/ASN.2013050518.

75. Jin B, Liu L, Zhang S, Cao X, Xu Y, Wang J, Sun L. Nuclear Magnetic Resonance-Assisted Metabolic Analysis of Plasma for Mild Gestational Diabetes Mellitus Patients. Metab Syndr Relat Disord. 2017; 15:439-49. https:/doi. org/10.1089/met.2017.0065.

76. Schliefsteiner C, Peinhaupt M, Kopp S, Logl J, Lang-Olip I, Hiden U, Heinemann A, Desoye G, Wadsack C. Human Placental Hofbauer Cells Maintain an Anti-inflammatory M2 Phenotype despite the Presence of Gestational Diabetes Mellitus. Front Immunol. 2017; 8:888. https://doi. org/10.3389/fimmu.2017.00888.

77. Pendeloski KP, Mattar R, Torloni MR, Gomes CP, Alexandre SM, Daher S. Immunoregulatory molecules in patients with gestational diabetes mellitus. Endocrine. 2015; 50:99-109. https://doi.org/10.1007/s12020-015-0567-0.

78. Ferjeni Z, Bouzid D, Fourati H, Stayoussef M, Abida O, Kammoun T, Hachicha M, Penha-Goncalves C, Masmoudi H. Association of TCR/CD3, PTPN22, CD28 and ZAP70 gene polymorphisms with type 1 diabetes risk in Tunisian population: family based association study. Immunol Lett. 2015; 163:1-7. https://doi.org/10.1016/j.imlet.2014.11.005.

79. Wang CJ, Heuts F, Ovcinnikovs V, Wardzinski L, Bowers C, Schmidt EM, Kogimtzis A, Kenefeck R, Sansom DM, Walker LS. CTLA-4 controls follicular helper T-cell differentiation by regulating the strength of CD28 engagement. Proc Natl Acad Sci U S A. 2015; 112:524-9. https://doi.org/10.1073/pnas.1414576112.

80. Attridge K, Kenefeck R, Wardzinski L, Qureshi OS, Wang CJ, Manzotti C, Okkenhaug K, Walker LS. IL-21 promotes $\mathrm{CD} 4 \mathrm{~T}$ cell responses by phosphatidylinositol 
3-kinase-dependent upregulation of CD86 on B cells. J Immunol. 2014; 192:2195-201. https://doi.org/10.4049/ jimmunol.1302082.

81. Yadav D, Judkowski V, Flodstrom-Tullberg M, Sterling L, Redmond WL, Sherman L, Sarvetnick N. B7-2 (CD86) controls the priming of autoreactive CD4 $\mathrm{T}$ cell response against pancreatic islets. J Immunol. 2004; 173:3631-9.

82. Strioga M, Pasukoniene V, Characiejus D. CD8+CD28- and CD8+ CD57+ T cells and their role in health and disease. Immunology. 2011; 134:17-32. https://doi.org/10.1111/ j.1365-2567.2011.03470.x.

83. Mikulkova Z, Praksova P, Stourac P, Bednarik J, Strajtova L, Pacasova R, Belobradkova J, Dite P, Michalek J. Numerical defects in CD8+CD28- T-suppressor lymphocyte population in patients with type 1 diabetes mellitus and multiple sclerosis. Cell Immunol. 2010; 262:75-9. https:// doi.org/10.1016/j.cellimm.2010.02.002.

84. Jain N, Miu B, Jiang JK, McKinstry KK, Prince A, Swain SL, Greiner DL, Thomas CJ, Sanderson MJ, Berg LJ, Kang J. CD28 and ITK signals regulate autoreactive T cell trafficking. Nat Med. 2013; 19:1632-7. https://doi. org/10.1038/nm.3393.

85. Hutloff A, Dittrich AM, Beier KC, Eljaschewitsch B, Kraft R, Anagnostopoulos I, Kroczek RA. ICOS is an inducible T-cell co-stimulator structurally and functionally related to CD28. Nature. 1999; 397:263-6. https://doi. org/10.1038/16717.

86. Hawiger D, Tran E, Du W, Booth CJ, Wen L, Dong C, Flavell RA. ICOS mediates the development of insulindependent diabetes mellitus in nonobese diabetic mice. $\mathrm{J}$ Immunol. 2008; 180:3140-7.

87. Kornete M, Sgouroudis E, Piccirillo CA. ICOSdependent homeostasis and function of Foxp3+ regulatory $\mathrm{T}$ cells in islets of nonobese diabetic mice. J Immunol. 2012; 188:1064-74. https://doi.org/10.4049/ jimmunol.1101303.

88. Kryczek I, Wei S, Zou L, Zhu G, Mottram P, Xu H, Chen L, Zou W. Cutting edge: induction of B7-H4 on APCs through IL-10: novel suppressive mode for regulatory T cells. J Immunol. 2006; 177:40-4.

89. Kryczek I, Zou L, Rodriguez P, Zhu G, Wei S, Mottram P, Brumlik M, Cheng P, Curiel T, Myers L, Lackner A, Alvarez X, Ochoa A, et al. B7-H4 expression identifies a novel suppressive macrophage population in human ovarian carcinoma. J Exp Med. 2006; 203:871-81. https://doi. org/10.1084/jem.20050930.

90. Podojil JR, Liu LN, Marshall SA, Chiang MY, Goings GE, Chen L, Langermann S, Miller SD. B7-H4Ig inhibits mouse and human T-cell function and treats EAE via IL-10/Tregdependent mechanisms. J Autoimmun. 2013; 44:71-81. https://doi.org/10.1016/j.jaut.2013.04.001.

91. Azuma T, Zhu G, Xu H, Rietz AC, Drake CG, Matteson EL, Chen L. Potential role of decoy B7-H4 in the pathogenesis of rheumatoid arthritis: a mouse model informed by clinical data. PLoS Med. 2009; 6:e1000166. https://doi.org/10.1371/ journal.pmed.1000166.

92. Chen L, Lu Y, Wang F, Zhou M, Chu Y, Ding W, Liu C, Xie $\mathrm{J}$, Wu C, Jiang J. Expression of co-stimulatory molecule B7-H4 in patients suffering from rheumatoid arthritis. Immunol Lett. 2013; 154:25-30. https://doi.org/10.1016/j. imlet.2013.07.009.

93. Yuan CL, Xu JF, Tong J, Yang H, He FR, Gong Q, Xiong P, Duan L, Fang M, Tan Z, Xu Y, Chen YF, Zheng F, et al. B7H4 transfection prolongs beta-cell graft survival. Transpl Immunol. 2009; 21:143-9. https://doi.org/10.1016/j. trim.2009.03.007.

94. Radichev IA, Maneva-Radicheva LV, Amatya C, Parker C, Ellefson J, Wasserfall C, Atkinson M, Burn P, Savinov AY. Nardilysin-dependent proteolysis of cell-associated VTCN1 (B7-H4) marks type 1 diabetes development. Diabetes. 2014; 63:3470-82. https://doi.org/10.2337/db14-0213.

95. Radichev IA, Maneva-Radicheva LV, Amatya C, Salehi M, Parker C, Ellefson J, Burn P, Savinov AY. Loss of Peripheral Protection in Pancreatic Islets by ProteolysisDriven Impairment of VTCN1 (B7-H4) Presentation Is Associated with the Development of Autoimmune Diabetes. J Immunol. 2016; 196:1495-506. https://doi.org/10.4049/ jimmunol.1403251.

96. Wang X, Hao J, Metzger DL, Mui A, Ao Z, Akhoundsadegh $\mathrm{N}$, Langermann S, Liu L, Chen L, Ou D, Verchere CB, Warnock GL. Early treatment of NOD mice with B7-H4 reduces the incidence of autoimmune diabetes. Diabetes. 2011; 60:3246-55. https://doi.org/10.2337/db11-0375.

97. Wang X, Hao J, Metzger DL, Mui A, Lee IF, Akhoundsadegh N, Ao Z, Chen L, Ou D, Verchere CB, Warnock GL. Endogenous expression of B7-H4 improves long-term murine islet allograft survival. Transplantation. 2013; 95:94-9. https://doi.org/10.1097/ TP.0b013e318277229d.

98. Seijkens T, Kusters P, Engel D, Lutgens E. CD40CD40L: linking pancreatic, adipose tissue and vascular inflammation in type 2 diabetes and its complications. Diab Vasc Dis Res. 2013; 10:115-22. https://doi. org/10.1177/1479164112455817.

99. Baker RL, Mallevaey T, Gapin L, Haskins K. T cells interact with $\mathrm{T}$ cells via CD40-CD154 to promote autoimmunity in type 1 diabetes. Eur J Immunol. 2012; 42:672-80. https:// doi.org/10.1002/eji.201142071.

100. Nanji SA, Hancock WW, Luo B, Schur CD, Pawlick RL, Zhu LF, Anderson CC, Shapiro AM. Costimulation blockade of both inducible costimulator and CD40 ligand induces dominant tolerance to islet allografts and prevents spontaneous autoimmune diabetes in the NOD mouse. Diabetes. 2006; 55:27-33.

101. Vaitaitis GM, Olmstead MH, Waid DM, Carter JR, Wagner DH Jr. A CD40-targeted peptide controls and reverses type 1 diabetes in NOD mice. Diabetologia. 2014; 57:2366-73. https://doi.org/10.1007/s00125-014-3342-5. 
102. Poggi M, Jager J, Paulmyer-Lacroix O, Peiretti F, Gremeaux T, Verdier M, Grino M, Stepanian A, Msika S, Burcelin R, de Prost D, Tanti JF, Alessi MC. The inflammatory receptor CD40 is expressed on human adipocytes: contribution to crosstalk between lymphocytes and adipocytes. Diabetologia. 2009; 52:1152-63. https://doi.org/10.1007/ s00125-009-1267-1.

103. Missiou A, Wolf D, Platzer I, Ernst S, Walter C, Rudolf P, Zirlik K, Kostlin N, Willecke FK, Munkel C, Schonbeck $\mathrm{U}$, Libby P, Bode C, et al. CD40L induces inflammation and adipogenesis in adipose cells--a potential link between metabolic and cardiovascular disease. Thromb Haemost. 2010; 103:788-96. https://doi.org/10.1160/TH09-07-0463.

104. Wolf D, Jehle F, Ortiz Rodriguez A, Dufner B, Hoppe N, Colberg C, Lozhkin A, Bassler N, Rupprecht B, Wiedemann A, Hilgendorf I, Stachon P, Willecke F, et al. CD40L deficiency attenuates diet-induced adipose tissue inflammation by impairing immune cell accumulation and production of pathogenic IgG-antibodies. PLoS One. 2012; 7:e33026. https://doi.org/10.1371/journal.pone.0033026.

105. Poggi M, Engel D, Christ A, Beckers L, Wijnands E, Boon L, Driessen A, Cleutjens J, Weber C, Gerdes N, Lutgens E. CD40L deficiency ameliorates adipose tissue inflammation and metabolic manifestations of obesity in mice. Arterioscler Thromb Vasc Biol. 2011; 31:2251-60. https://doi.org/10.1161/ATVBAHA.111.231357.

106. Wolf D, Jehle F, Michel NA, Bukosza EN, Rivera J, Chen YC, Hoppe N, Dufner B, Rodriguez AO, Colberg C, Nieto L, Rupprecht B, Wiedemann A, et al. Coinhibitory suppression of $\mathrm{T}$ cell activation by $\mathrm{CD} 40$ protects against obesity and adipose tissue inflammation in mice. Circulation. 2014; 129:2414-25. https://doi.org/10.1161/ CIRCULATIONAHA.113.008055.

107. Vinay DS, Kwon BS. Role of 4-1BB in immune responses. Semin Immunol. 1998; 10:481-9. https://doi.org/10.1006/ smim.1998.0157.

108. Tu TH, Kim CS, Kang JH, Nam-Goong IS, Nam CW, Kim ES, Kim YI, Choi JI, Kawada T, Goto T, Park T, Yoon Park $\mathrm{JH}$, Choi MS, et al. Levels of 4-1BB transcripts and soluble 4-1BB protein are elevated in the adipose tissue of human obese subjects and are associated with inflammatory and metabolic parameters. Int J Obes (Lond). 2014; 38:107582. https://doi.org/10.1038/ijo.2013.222.

109. Tu TH, Kim CS, Goto T, Kawada T, Kim BS, Yu R. 4-1BB/4-1BBL interaction promotes obesity-induced adipose inflammation by triggering bidirectional inflammatory signaling in adipocytes/macrophages. Mediators Inflamm. 2012; 2012:972629. https://doi. org/10.1155/2012/972629.

110. Kim CS, Kim JG, Lee BJ, Choi MS, Choi HS, Kawada T, Lee KU, Yu R. Deficiency for costimulatory receptor 4-1BB protects against obesity-induced inflammation and metabolic disorders. Diabetes. 2011; 60:3159-68. https:// doi.org/10.2337/db10-1805.

111. Sytwu HK, Lin WD, Roffler SR, Hung JT, Sung HS, Wang CH, Cheng TL, Tsou SC, Hsi SC, Shen KL. Anti-4-1BBbased immunotherapy for autoimmune diabetes: lessons from a transgenic non-obese diabetic (NOD) model. J Autoimmun. 2003; 21:247-54. 